\title{
The Quality of Alkali Treated Cottonii (ATC) Made from Eucheuma cottonii Collected from Different Regions In Indonesia
}

\section{Kualitas Alkali Treated Cottonii (ATC) yang Dibuat dari Rumput Laut Eucheuma cottonii yang Berasal dari Beberapa Daerah di Indonesia}

\author{
Muhamad Darmawan ${ }^{1 *}$, Bagus Sediadi Bandol Utomo and Raekal Amral Yuda Mulia ${ }^{2}$ \\ ${ }^{1}$ Research and Development Center for Marine and Fisheries Product Processing and Biotechnology, Jl. K.S. Tubun \\ Petamburan VI, Jakarta Pusat 10260, Indonesia \\ 2 Swiss German University, Jalan Raya Bumi Serpong Damai Sektor 1, Tangerang Selatan 15321 \\ ${ }^{*}$ Correspondence Author: m.darmawan22@gmail.com \\ Article history: \\ Received: 16 Mei 2013; Revised: 7 November 2013; Accepted: 8 November 2013
}

\begin{abstract}
The presented study has been carried out in order to study the quality of Alkali Treated Cottonii (ATC) made from Eucheuma cottonii which being collected from different regions in Indonesia (Belitung, Nusa Tenggara Barat and Lampung). The quality variables analyzed were the characteristics of raw materials (Clean anhydrous weed and impurities) and the characteristics of ATC produced (moisture content, ash content, acid insoluble ash content, yield, gel strength, sulphate content, gelling -melting point). The analysis was done in 3 replicates and the data were statistically analyzed using SPSS 15 package software. Results indicated that the raw material from Lampung had a better quality than those from Nusa Tenggara Barat and Belitung. In addition, the characteristics of ATC produced from these three raw materials showed that seaweed from Lampung produced better quality ATC than those from Nusa Tenggara Barat and Belitung in terms of their gel strength, sulphate content and yield.
\end{abstract}

Keywords: alkali treated cottonii (ATC), Eucheuma cottonii, quality

\section{ABSTRAK}

Penelitian mengenai pembuatan Alkali Tretated Cottonii (ATC) dari rumput laut Eucheuma cottoniii dari beberapa wilayah di Indonesia (Belitung, Nusa Tenggara Barat, dan Lampung) telah dilaksanakan dalam rangka mengetahui kualitas ATC yang dibuat. Pengamatan dilakukan terhadap karakteristik bahan baku rumput laut (Clean anhydrous weed dan impurities) serta karakteristik ATC yang dihasilkan (kadar air, kadar abu, kadar abu tak larut asam, rendemen, kekuatan gel, kadar sulfat dan titik jendal dan titik leleh). Analisa dilakukan dengan 3 kali ulangan dan datanya dianalisa menggunakan paket program (software) SPSS 15. Hasil penelitian menunjukkan bahwa bahan baku yang berasal dari Lampung memiliki kualitas yang lebih baik dibandingkan dengan bahan baku yang berasal dari Nusa Tenggara Barat dan Belitung. Demikian pula dengan hasil karakterissasi ATC yang dihasilkan. ATC yang dihasilkan dari rumput laut yang berasal dari Lampung memiliki mutu paling baik terutama dari segi kekuatan gel, kadar sulfat, dan rendemen yang dihasilkan.

Kata Kunci: ATC, Eucheuma cottonii, kualitas

Permalink/DOI: http://dx.doi.org/10.15578/squalen.v8i3.37

\section{Introduction}

Seaweed is one of the six primary commodities which being developed recently at several potential locations in Indonesia. The production of seaweed has been increasing rapidly in the past following years. According to International Finance Corporation (2006), seaweed is a major source of income for tens of thousands of small Indonesian farmers, collectors, traders, exporters as well as processors. In terms of natural resources, Indonesian waters have many advantages on the climatic condition for seaweed growth having warm waters rich in nutrients and extensive coastline with shallow waters which are suited for seaweed production (Anonymous, 2004).

As an archipelagic nation, Indonesia has 1.2 million hectare of potential area that can be used for planting seaweed and produce 16 ton dry seaweed per hectare. If all of that potential areas are used optimally, then the production of seaweed in Indonesia can reach 17.774.400 tons per annum (DKP, 2008). The government has realized about the potential to develop this commodity. The Minister of Marine Affairs and Fisheries has made a target that in 2014, Indonesia can produce 10 million tons of seaweed. That target 
was double compared with seaweed production in 2012 which was only 5 million tons a year (Anonymous, 2013).

The world demand on dry carrageenan producing seaweed increases every year. The world annual production of this extract was about 250.000 tones (IFC, 2006), so that the government intends to increase the production of seaweed in Indonesia to fulfill the world demand and become one of the biggest exporters in the world. In the other side, the government also intends to uplift the socio-economic status of coastal population by developing seaweed industry. This seaweed farming is very promising to be developed by the coastal people to improve their economic status. The seaweed farming technology is relatively simple and it requires low initial capital investment. With only 45 days of farming cycles with a very good price, seaweed farming can provide a high return of investment for the coastal population.

Seaweed farming is developed in several regions in Indonesia like South Sulawesi, Bali, Lampung, Nusa Tenggara Barat, and many other regions. Nusa Tenggara Barat Province is well known as one of the primary seaweed producers in Indonesia. In 2006, Nusa Tenggara Barat province produced 32.000 ton of seaweeds and in 2011, the production of seaweed has reached 400.000 ton of seaweeds. Lampung, and Bangka Belitung also have a great number of seaweed productions. Several species of seaweed are cultivated at the regions, but mostly only three types of seaweed are cultivated in Indonesia (Eucheuma cottonii, Eucheuma spinosum, and Gracilaria sp.). Seaweed from those regions is mostly exported to China, Denmark, Spain, United States, and some other countries.

The seaweeds were exported in the form of dry seaweed as a raw material for industries. The price for dry seaweed exported to several countries was very low compared with processed or semi processed products like Alkali Treated Cottonii (ATC) or Refined Carrageenan (RC). The government has a program to restrict exports of raw material from 2012 to increase domestic processed products. The government would control export volumes by only allowing raw seaweed exporters to export a certain amount rather than by introducing an export tax. Indonesia supplies about half of the world's raw seaweed, which is used by the food industry and as an ingredient in health products and cosmetics. The government aims to accelerate the development of the domestic processing industry by 2012 by encouraging the private sector to invest in seaweed processing (Ekawati, 2010).

Alkali Treated Cottonii is one of the products which are very potential to be developed in Indonesia. Several ATC factories have already existed in Indonesia like in Bali, Malang, and South Sulawesi. The information about the quality of ATC made from Eucheuma cottonii is still very limited, though the information is very important especially for seaweed processing companies. This research was carried out to get important information about the quality of ATC made from Eucheuma cottonii collected from Belitung and Lampung in Sumatera Island and from Nusa Tenggara Barat in eastern part of Indonesia.

\section{Material and Methods}

\subsection{Seaweed Materials}

Seaweed used in this research was collected from three different regions of Indonesia (Belitung, Lampung and Nusa Tenggara Barat), and bought from local seaweed traders or exporters. The dried seaweed was sorted to remove filth or any non-algal materials such as rope, sand, and other materials found in the seaweed. This process is also aimed to remove other seaweed species than E. cottonii. After the sorting process, the seaweed was then packed into plastic bag and sent to the Processing Laboratory of Research Center for Marine and Fisheries Product Processing and Biotechnology in Jakarta.

\subsection{Methods}

Raw Material Characterization. To characterize the raw materials, two important parameters were evaluated, namely Clean Anhydrous Weed (CAW) and the percentage of the impurities. Besides, the description of raw materials is thoroughly observed including observation of the size and color of the thallus, the dryness of the seaweed, whether the seaweed is dirty or clean, whether there is still much salt stick in the thallus, and the age the seaweed when harvested.

Alkali Treated Cottonii Production and Characterization. The processing of ATC was started by cleaning the dry seaweed to remove the impurities like sand and salt. The clean seaweed was then placed in a water bath containing of $8 \%$ of $\mathrm{KOH}$ solution for alkali treatment. The temperature was set at $80^{\circ} \mathrm{C}$ for 2 hours. The sample was washed 3 times with fresh water, chopped around $1 \mathrm{~cm}$ long and sun dried. The drying process was done for 3 days. For the purpose of analysis, the product was ground and filtered with 60 mesh filter to make ATC powder. The flow diagram of ATC processing is presented in Figure 1.

The quality parameters of ATC being evaluated were yield (FMC corp., 1977), gel strength (Marine Colloids, 1978), moisture content (AOAC, 1995), total 


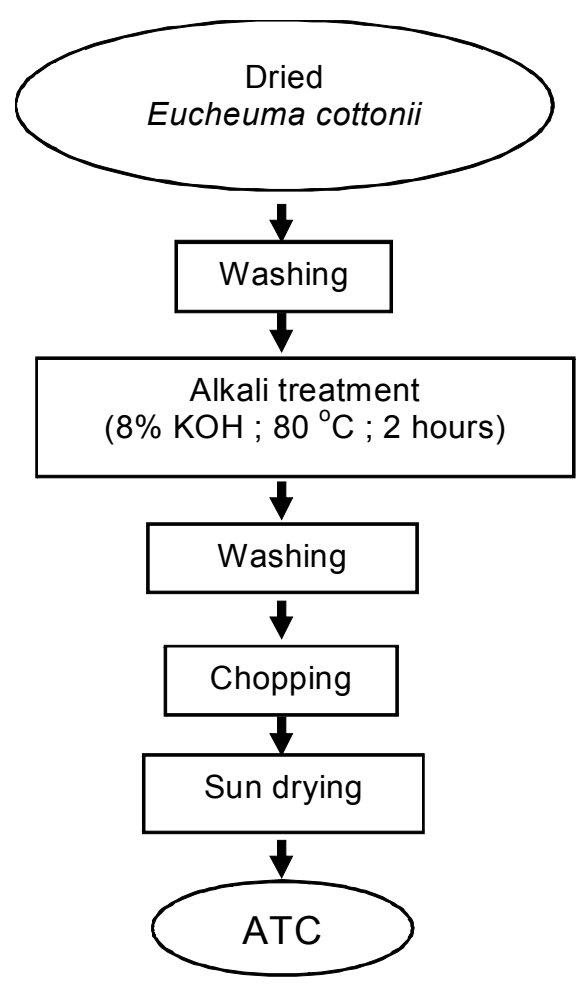

Figure 1. Flow diagram of ATC Processing

ash content (AOAC, 1995), acid insoluble ash content (FMC corp., 1977), sulfate content (FMC corp., 1977), gelling and melting point (Marine Colloids, 1978). The analysis was done in 3 replicates and the data were statistically analyzed by one way analysis of variance using SPSS 15 package.

\section{Results and Discussion}

\subsection{Raw Materials Characterization}

Results of raw material analysis of Eucheuma cottonii collected from Belitung, Nusa Tenggara Barat, and Lampung are presented in Table 1.

The important parameters observed in dry seaweed or raw materials are CAW and impurities. These parameters indicate the purity of raw materials that can be used for the processing information. The FAO standard for CAW of raw materials is less than $30 \%$. If the CAW value is higher than the standard it can be assumed that the raw materials contains many other materials like sand and salt that stick in to the seaweed. The CAW test was conducted to see the dry solid content of pure seaweed and as indicator of impurities stick on the seaweed plant (Seaplant, 2008). The CAW results for raw materials from 3 regions were different one another (Table 1). All the CAW results indicated that the raw materials from those three regions still have a lot of sand and salt stick in to the seaweed. These values do not meet the requirement of FAO standard ie. less than $30 \%$. The CAW value of the raw materials from Belitung is the highest. Meanwhile the CAW value of raw materials from Nusa Tenggara Barat is the lowest.

This condition can be affected by the technique of drying process applied by the farmers. Most of the seaweed farmers put the seaweed in to the uncovered ground or above the sand to do the drying process. Several farmers who already known the good technique to dry the seaweed usually use plastic to cover it from sand or they used para-para made from bamboo or wood to prevent the contact between seaweed and the sand.

The impurities values indicated that there were still some materials such as plastic rope or other seaweed species in the raw materials. The seaweed from Nusa Tenggara Barat has the lowest value of CAW but it has the highest value for the impurities. Normally, it can be happen if the farmers do not pay attention on the purity of the raw materials. The sorting process is not conducted properly.

Government effort to improve the quality of raw materials in the seaweed production sites has been done through research institutions, extension officers and regional offices. Improved methods of cultivation, harvesting time, and handling have been extensively disseminated to the farmers throughout the production 
Table 1. The characteristics of Eucheuma cottonii from the three regions

\begin{tabular}{llr}
\hline Seaweed Resources & $\begin{array}{c}\text { Clean Anhydrous } \\
\text { Weed /CAW (\%) }\end{array}$ & Impurities (\%) \\
\hline Belitung & $62.57 \pm 12.45$ & $5.78 \pm 1.45$ \\
Nusa Tenggara Barat & $44.54 \pm 1.69$ & $14.25 \pm 1.29$ \\
Lampung & $51.62 \pm 0.01$ & $5.36 \pm 0.21$ \\
\hline
\end{tabular}

Table 2. The description of seaweed from 3 different regions

\begin{tabular}{lll}
\hline Source & \multicolumn{1}{c}{ Description of The Sample } \\
\hline Belitung & $\begin{array}{l}\text { Thallus: huge and enough to be harvested } \\
\text { Color: yellowish white and and dark brown } \\
\text { Filth: small amount of sand and soil } \\
\text { Salt: small amount of salt } \\
\text { Dryness: dry } \\
\text { Harvesting period: } 45 \text { Days }\end{array}$ \\
Nusa Tenggara Barat & $\begin{array}{l}\text { Thallus: huge and enough to be harvested } \\
\text { Color: dark Brown and yellowish black } \\
\text { Filth: a lot of sand and soil } \\
\text { Salt: a lot of salt } \\
\text { Dryness: dry } \\
\text { Harvesting period: } 45 \text { days }\end{array}$ \\
& $\begin{array}{l}\text { Thallus: huge and enough to be harvested } \\
\text { Color: black and dark brown } \\
\text { Filth: small amount of sand and soil } \\
\text { Salt: small amount of salt } \\
\text { Dryness: dry } \\
\text { Harvesting period: } 45 \text { days }\end{array}$ \\
&
\end{tabular}

regions. This effort is very important to improve the quality of the raw material, to gain the additional value of the seaweed and finally increase the farmer's income.

Beside CAW and Impurities, an observation of raw materials also has been done to get descriptive information about the condition of raw materials from Belitung, Lampung and, Nusa Tenggara Barat. The description of seaweed from 3 different regions was shown in Table 2.

The moisture content of ATC resulted in this experiment as presented in Figure 2 was ranged from $6.62 \pm 0.12 \%$ to $10.42 \pm 0.09 \%$. Figure 2 showed that the highest moisture content of ATC was obtained by the ATC product made from seaweed collected from Belitung, while lowest moisture content of ATC was by the ATC product made from seaweed collected from Lampung. All the products had met the moisture content standard made by FAO in 2007 (12\%). Moisture content of ATC from those 3 regions was significantly different $(p<0.05)$. The moisture content of product can be affected by several factors. The drying technique is one of the factors that can affect the moisture content. The drying technique used in this research was by solar drying. The period of time needed to dry the product was different between one and another because it all depends on the weather condition. One of other factors that might influence the water content of ATC product is the heat intensity during sun drying. The moisture content of ATC is important as the lower the water content, the longer the shelf life or in other words the slower the product to deteriorate.

\subsection{Ash Content}




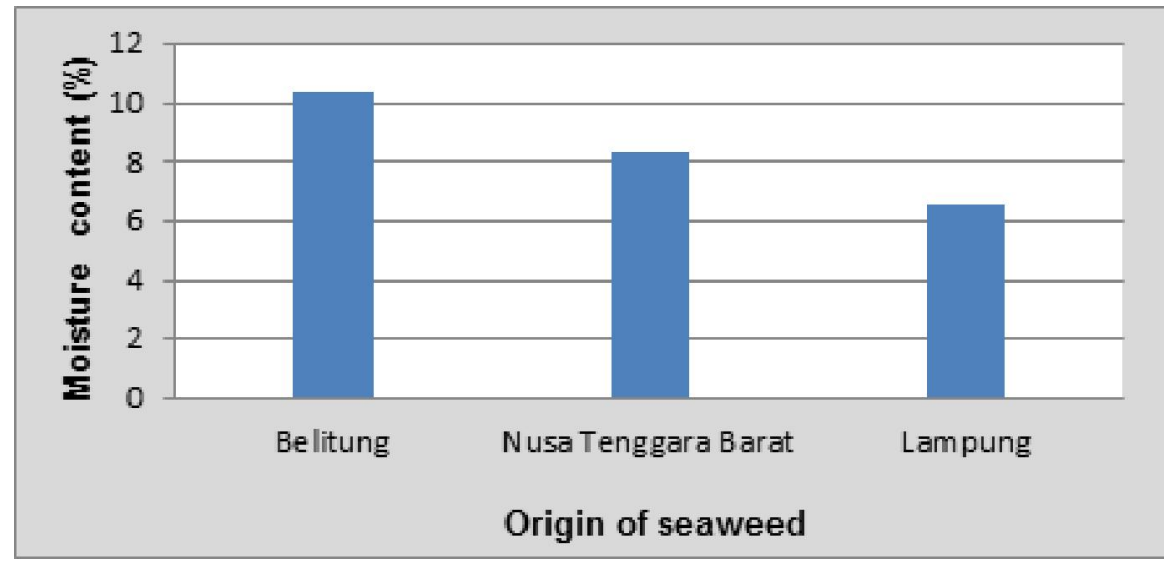

Figure 2. The moisture content of ATC from different seaweed resources.

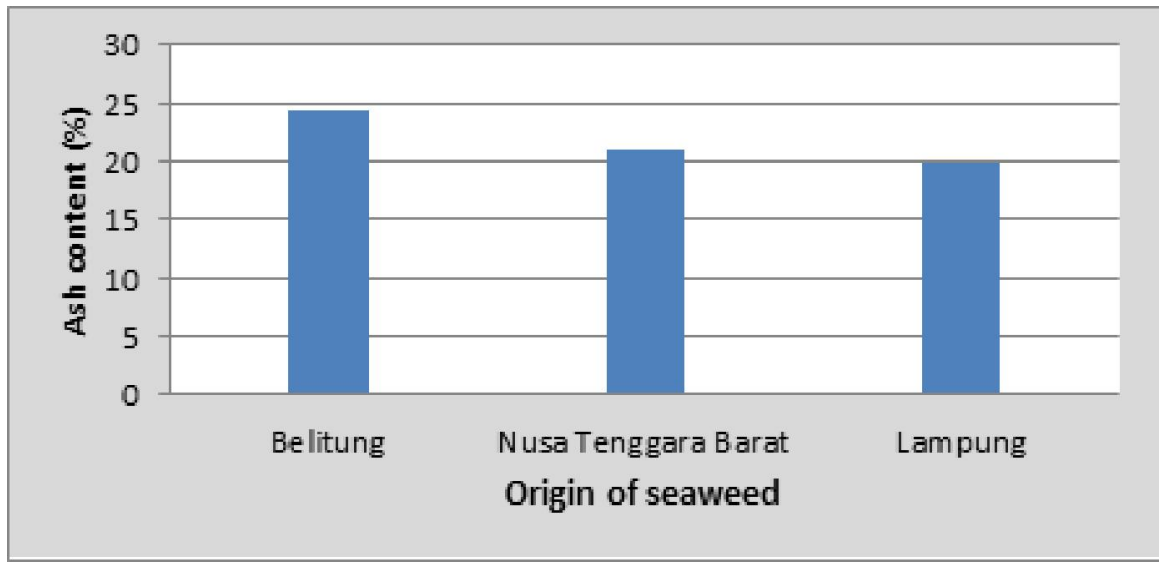

Figure 3. The ash content of ATC from different seaweed resources.

Ash content analysis was conducted to determine the general mineral content contained in ATC product. There are 2 major types of ashing, first, dry ashing and second, wet ashing (Marshall, 2010). The ashing type used in this study was dry ashing where water and volatile compound vaporized by heating at $500-$ $600^{\circ} \mathrm{C}$. Ash content value of a food indicates the large amount of minerals contained in these foodstuffs (Apriyantono et al., 1989). Sudarmadji et al., (1996) states that the minerals contained in a material can be differentiated into two kinds of salts, which are organic and inorganic salts. Chemicals that evaporate during combustion process such as water and other volatile substances will be oxidized to produce $\mathrm{CO}_{2}$. Seaweed contain high mineral such as $\mathrm{Na}, \mathrm{K}, \mathrm{Cl}$, and $\mathrm{Mg}$. The ash content of ATC from different seaweed resources can be seen in Figure 3.

The ash content of ATC resulted in this experiment as presented in Figure 3 ranged from $19.82 \pm 0.04 \%$ to $24.33 \pm 0.10 \%$. Figure 3 showed that the highest ash content of ATC was obtained by the ATC product made from seaweed collected from Belitung, while lowest ash content of ATC was by the ATC product made from seaweed collected from Lampung. FAO standard (2007) for the ash content of carrageenan is $15-40 \%$, meanwhile the Food Chemical Codex standard (1981) for the ash content is $35 \%$ maximum. The ash content of ATC made in this research has fulfilled the entire standard mentioned above.

Statistical analysis indicated that the ash content of ATC product made from seaweed collected from 3 regions was significantly different $(p<0,05)$. The origin of the raw materials and life cycles of the seaweed can influence the amount of ash content in ATC product. Seaweed is one of the commodities that have high mineral content in it. Basmal et al. (2003) reported that seaweed is one of the raw materials used in the industry that has high mineral content such as $\mathrm{Na}^{+}$, $\mathrm{K}^{+}, \mathrm{Ca}^{2+}$, dan $\mathrm{Mg}^{2+}$. Meanwhile Wenno et al. (2012) indicated that the longer life cycles of the seaweed, the higher the ash content of carrageenan produced.

The amount of mineral content in seaweed also can be affected by the environmental condition of the area where the seaweed was planted. The water movement supplies nutrients to the seaweed. It also 
helps the seaweed to absorb nutrients, cleaning the dirt, and establish the exchange of $\mathrm{CO}_{2}$ and $\mathrm{O}_{2}$. The absorption of nutrients through the entire members of the plant is not causing the nutrients to decrease. This means that the nutrients in the sea are still sufficient, even excessive to the need of seaweed because of good circulation, a run-off from land and water movement (Indriani \& Sumiarsih, 1991).

\subsection{Acid Insoluble Ash Content}

Acid insoluble ash is material that is insoluble in acid condition (Hydrochloric solution). Acid insoluble ash content indicates the existence of residual contamination of mineral or metal that cannot be dissolved in acid in a product, such as silica (Si), which is found in nature as quartz, stone, and sand. The effect of seaweed resources on the acid insoluble ash of ATC can be seen in Figure 4.

The acid insoluble ash content of ATC resulted in this experiment as presented in Figure 4 was ranged from $0.02 \pm 0.01 \%$ to $0.06 \pm 0.03 \%$. Figure 4 showed that the highest acid insoluble ash content of ATC was obtained by the ATC product made from seaweed collected from Belitung, while lowest acid insoluble ash content of ATC was by the ATC product made from seaweed collected from Nusa Tenggara Barat. FAO standard (2007) and Food Chemical Codex standard (1981) standard for the acid insoluble ash content of carrageenan is less than $1 \%$. The acid insoluble ash content of ATC product made from seaweed collected from 3 regions has suited the standard required above.

Statistical analysis showed that there was no significant difference for the acid insoluble ash content of ATC product made in this research ( $p>0.05$ ). Factors that can affect the amount of acid insoluble ash content are the raw materials handling process and the process to produce the ATC. The sorting process whether in raw materials handling process or in processing of ATC is an important step avoiding the high value of acid insoluble ash content. High acid insoluble acid indicates the contamination of mineral residue or acid insoluble metal that cannot be reduced optimally during the processing (Syamsuar, 2006). Low values indicate that the ATC chip produced were not contaminated during the process (Suryaningrum et al., 2003).

\subsection{Yield}

Yield is one of the important parameter. Yield is the ratio between the final product, which is ATC chips and the initial raw material (dried seaweed) that is used and multiplies with $100 \%$. Calculating the percentage of yield is very important because the quality of the raw materials for manufacturing ATC can be seen from the value of the yield that is produced from the alkali treatment. The effect of seaweed resources on the yield of ATC can be seen in Figure 5.

Yield of ATC that is produced in this research ranged from $30.01 \pm 2.49 \%$ to $41.33 \pm 1.04 \%$. Lampung has the highest value of yield among the other sources. The statistical analysis resulted that there was a significant difference in ATC yield at different seaweed resources $(p<0.05)$. According to the Tukey HSD test, there were a significant difference in yield of ATC between Belitung and Nusa Tenggara Barat and also between Belitung and Lampung, but there were no significant difference between Nusa Tenggara Barat and Lampung.

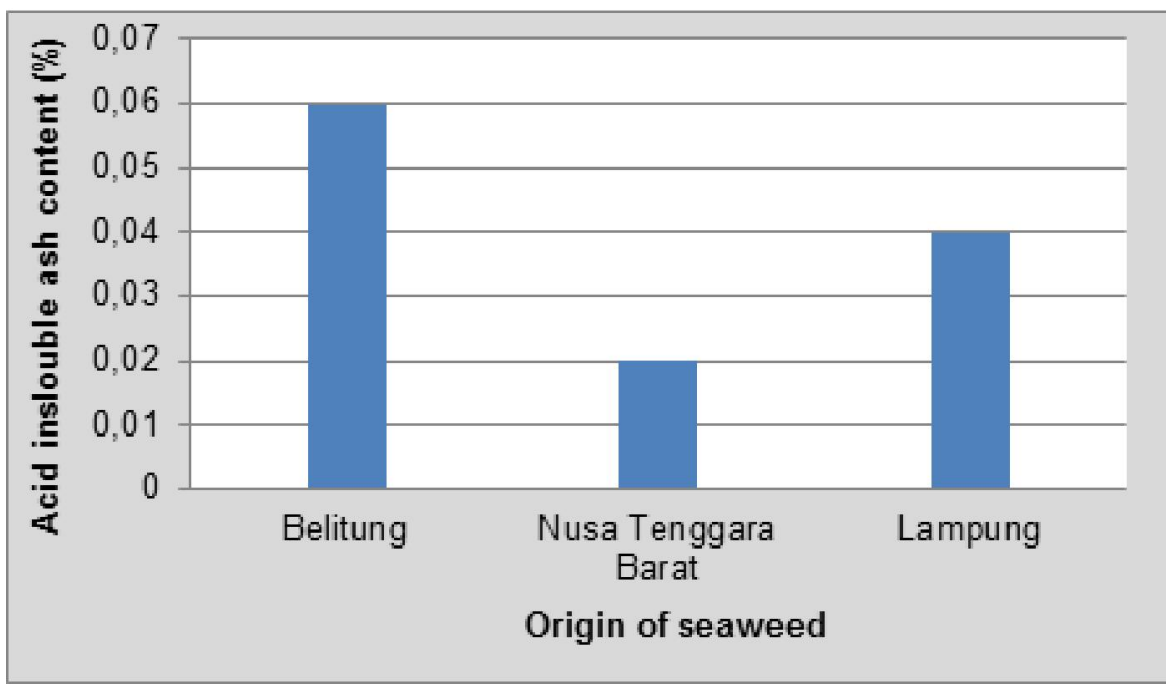

Figure 4. The acid insoluble ash content of ATC from different seaweed resources. 


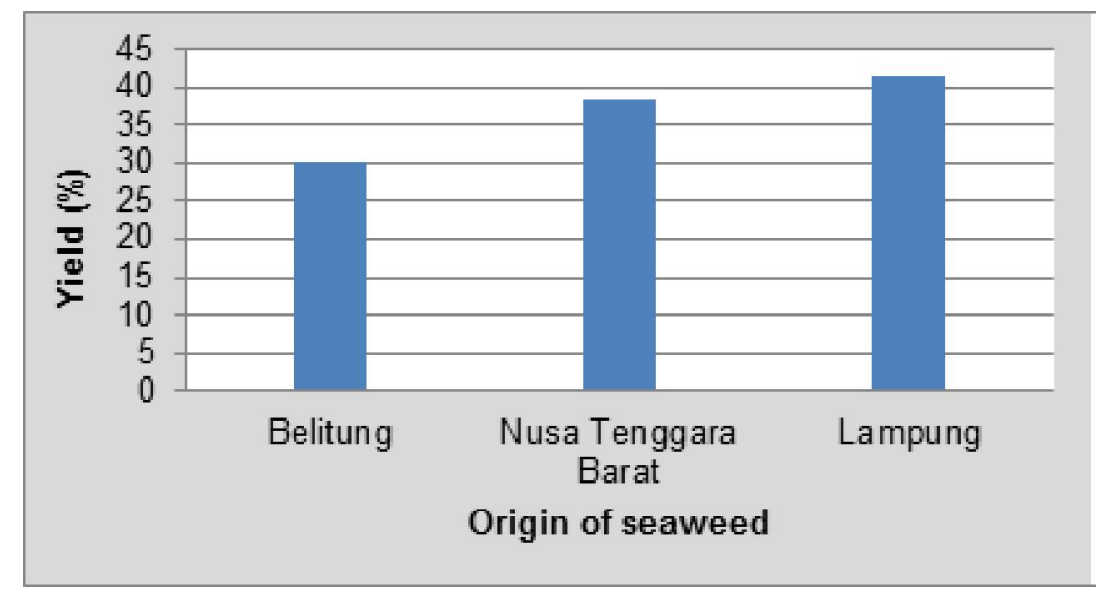

Figure 5. Yield of ATC from different seaweed resources.

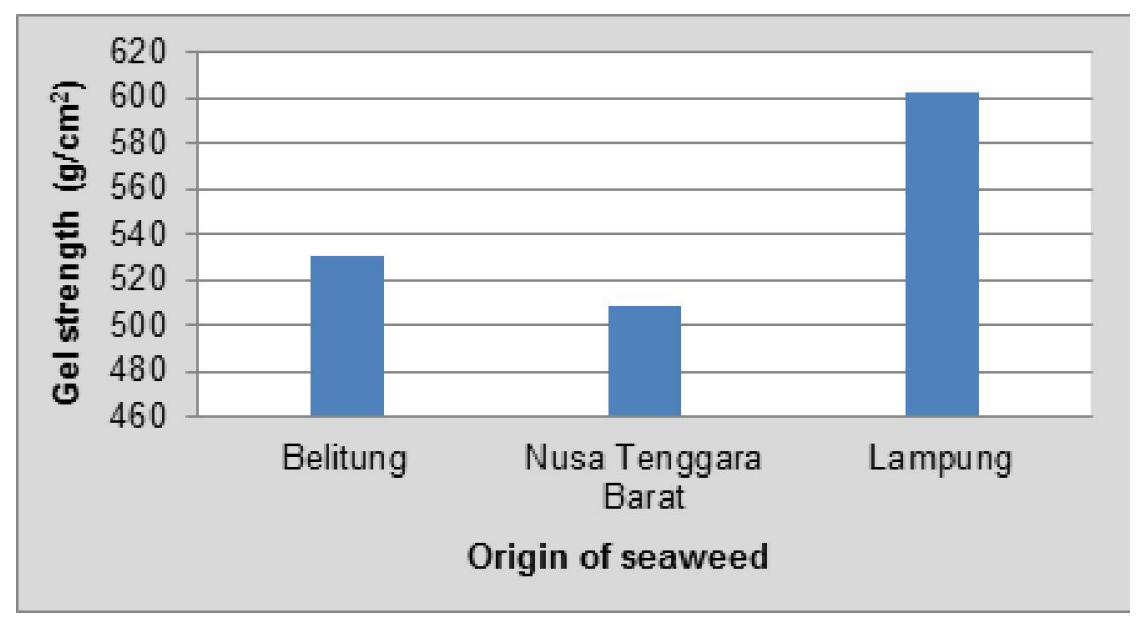

Figure 6. Gel strength of ATC from different seaweed resources.

The yield of ATC product can be influenced by several factors such as the processing technique and the raw materials used in the process. Basmal et al. (2009) states that the yield of carrageenan can be influenced by temperature and time used in the extraction process. Meanwhile, Istini \& Zatnika showed that yield of carragenan can be enhanced by the enhancement of $\mathrm{KOH}$ concentration used in the process. Chapman \& Chapman (1980) explained that the climate, method of extraction, harvesting time, and location of the cultivation influence the amount of yield. In addition, the water content also gives significant effect to yield, as higher water content would lead to heavier product produced in the process. The yield value of ATC product can be influenced not only by processing technique but also by the type of seaweed used, the age of seaweed when it cultivated and the environmental condition of the area where the seaweed was planted. (Jothisaraswathi et al., 2006).

\subsection{Gel Strength}

Gel strength as stated by Glicksman (1983) is one of the important physical properties. One of the important properties of ATC powder is the capability of reversible process of changing liquid to solid, or changes the form of solution into gel. The effect of seaweed resources on the gel strength of ATC can be seen in Figure 6.

Gel strength of ATC resulted in this experiment as presented in Figure 6 was ranged from 508,83 \pm 7.68 $\mathrm{g} / \mathrm{cm}^{2}$ to $602,89 \pm 9.09 \mathrm{~g} / \mathrm{cm}^{2}$. Figure 6 shows that the highest gel strength of ATC was obtained by the ATC product made from seaweed collected from Lampung, while lowest gel strength of ATC was by the ATC product made from seaweed collected from Nusa Tenggara Barat. Figure 6 shows that all gel strength results were within the standard of $F A O$ which is required to be larger than $400 \mathrm{grams} / \mathrm{cm}^{2}$. 


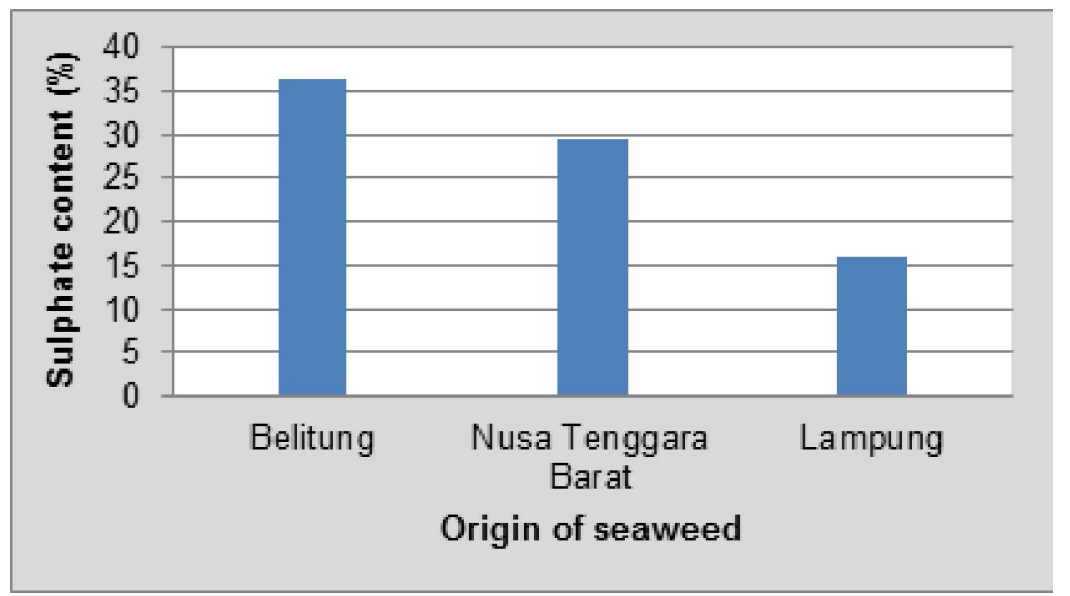

Figure 7. Sulphate content of ATC from different seaweed resources.

Several factors affected the gel strength value of carrageenan. Gelation of carrageenans, especially kappa, involves two separate and successive steps; coil-to-helix transition upon cooling and subsequent cation-dependent aggregation between helices (Campo et al., 2009). Glicksman (1983) stated that gel strength increase proportionally to 3,6 anhydrogalactose but inversely proportional to the sulfate content. The conversion of C- 6 in sulfate to 3,6 -anhydrogalactose is clearly creating new tough component. 3,6-anhydrogalactose causes the anhydropillic behavior and increases the formation of double helix, so thus yielding high gel strength.

The use of alkali in the process of making carrageenan can uplift the gel strength value. The presence of suitable cation, typically potassium or calcium, is an absolute requirement for gelation to proceed (Campo et al., 2009). For both iota and kappa-carrageenans, the alkali metal ions $(\mathrm{Li}+, \mathrm{Na}+$, $\mathrm{K}+, \mathrm{Rb}+, \mathrm{Cs}+)$ are all capable of inducing gelation, but $\mathrm{K}+$ and $\mathrm{Rb}+$ are considerably more effective than other ions in inducing gelation at much lower concentrations of both the cation and the carrageenan (Funami et al., 2007).

Syamsuar (2006) also suggest that the other factors influenced on high gel strength are raw material condition, age of cultivation, method of extraction and also the chemical used for extraction. Thus, the longer the raw material is stored, the lower gel strength resulted from the seaweed deterioration. So the faster the raw material is processed, the higher the gel strength value.

\subsection{Sulphate Content}

Sulphate content is used as parameter for different type of polysaccharides found in red algae (Winarno, 1996). Carrageenan is distinguished based on the sulfate content of the carrageenan precursor where $k$-carrageenan contains less than 28\% (Doty, 1987). Typically, commercial $k$-carrageenan contains $22 \%$ $(\mathrm{w} / \mathrm{w})$ of sulphate, $l$-carrageenan $32 \%(\mathrm{w} / \mathrm{w})$ and $\lambda$ carrageenan $38 \%(\mathrm{w} / \mathrm{w})$, although large variations can occur owing to differences between seaweed species or batches (De Ruiter\& Rudolph, 1997). The effect of seaweed resources on the sulphate content of ATC can be seen in Figure 7.

Sulphate content of ATC resulted in this experiment as presented in Figure 7 was ranged from $16.06 \pm 0.05$ to $36.37 \pm 1.68 \%$. Figure 7 showed that the highest sulphate content of ATC was obtained by the ATC product made from seaweed collected from Belitung, while the lowest sulphate content of ATC was by the ATC product made from seaweed collected from Lampung. Figure 7 shows that all sulphate content results were within the standard of FAO which is required to be between $15-40 \%$.

Statistical analysis indicated that the sulphate content of ATC product made from seaweed collected from 3 regions was significantly different $(p<0,05)$. There is a correlation between the sulphate content with the gel strength of ATC produced in this research. The lower the sulphate contents than the higher the gel strength value obtained. Experiment conducted by Hakim et al. (2011) indicated that carragenan which has highsulphate content has a high gel strength value. Gel strength of ATC increases proportionally to the 36-anhydrogalactose content but decreases proportionally to the sulphate content (Suryaningrum, 1988).

The technique process such as heating treatment and the use of alkali in the process also give significant effect of sulphate content and gel strength of carrageenan. Campo et al. (2009) stated that by heating the polysaccharide in strong alkaline media, 


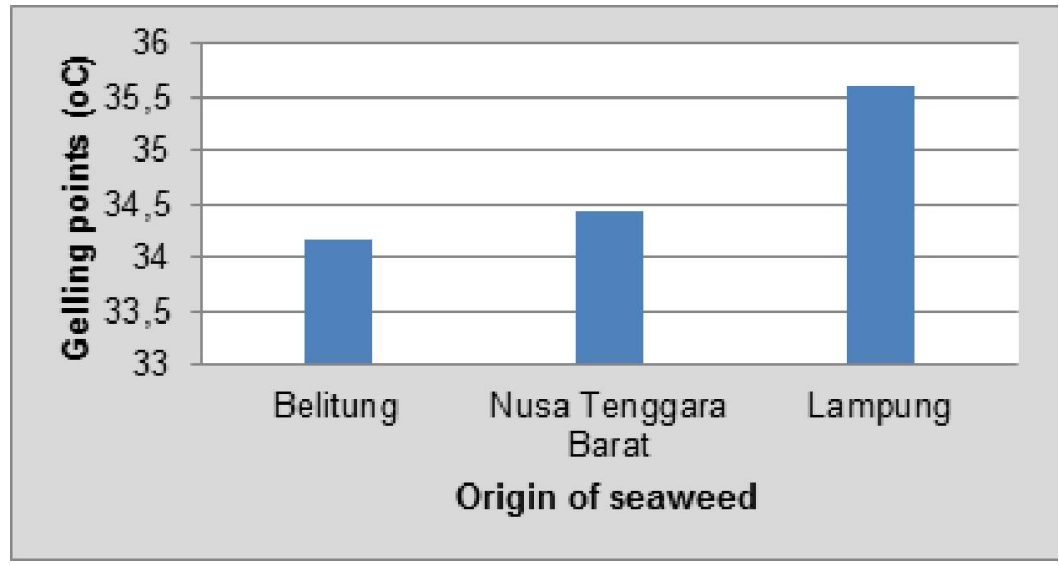

Figure 8.Gelling point of ATC from different seaweed resources.

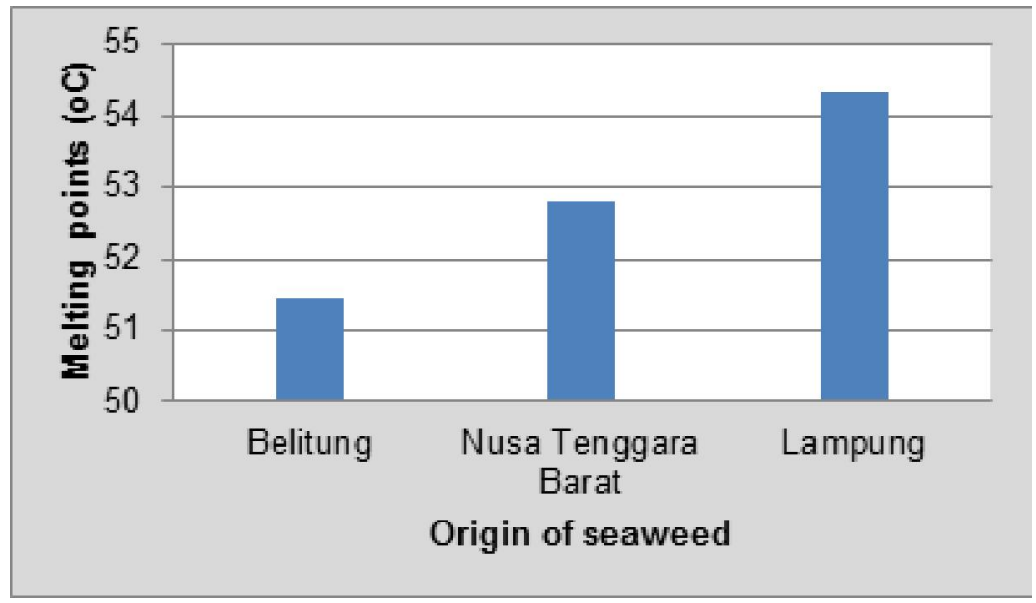

Figure 9. Melting point of ATC from different seaweed resources.

the free 3-OH group is ionized and produces an intramolecular nucleophilic displacement of the sulphate group at position 6. Another requirement for the helix formation is the ions present in solution. Potassium ions are able to be introduced between double helices and, as they neutralize the charges of sulphate groups, facilitate the approach between them. Potassium has also the property of stabilizing the double helix.

\subsection{Gelling and Melting Points}

The gelling point was the temperature at which the ATC form gel. This is one of the important factors for the food industry to choose which material should be used. The food producer is able to determine the temperature of the food product by knowing the gelling point, for example jelly, to form gel so that the minimum temperature should be applied to keep the quality of the jelly. In the other hand, the melting point can be used by food industry to determine the maximum temperature the food product that can be stored before it is consumed. The food producer will be able to know the maximum or minimum temperature required to maintain the quality of the food product. The effect of seaweed origin on the gelling and melting points of ATC can be seen in Figure 8 and 9.

The result of gelling point was ranged from $34.17 \pm$ 0.61 to $35.6 \pm 0.70^{\circ} \mathrm{C}$.In the other hand, the result of melting point was ranged from $51,47 \pm 0.97{ }^{\circ} \mathrm{C}$ to $54,33 \pm 0.75^{\circ} \mathrm{C}$. Based on the statistical analysis, there are no significant difference either gelling point or melting point of ATC from different sources $(p>0.05)$. This result proved that the ATC source will not give any significant effect on the gelling and melting point of the ATC.

Suryaningrum (1988) reported that the relation between melting point and the gelling point with the presence of the 3,6-anhydrogalactose are increased proportionally. The higher the presence of the 3,6anhydrogalactose, the higher the gelling and melting point. In the other hand, the relation between 3,6anhydrogalactose is inversely proportional to the 
sulfate content. This statement also enhanced by Syamsuar (2006) who declares that the sulfate presence tends to make the polymer in the form of sol. The forming of sol polymer will make the gelling process hard to be formed.

\section{Conclusion}

The quality of seaweed from Lampung, Belitung, and Nusa Tenggara Barat was different one another. The seaweed from Belitung has better quality with the high percentage of CAW and low percentage of impurities compared to the seaweed from Lampung and Nusa Tenggara Barat. All ATC product made from seaweed collected from the three regions meet the FAO standard for carrageenan. The seaweed from Lampung produce the best quality of ATC product in terms of gel strength, yield, and sulphate content compare to those from Belitung and Nusa Tenggara Barat.

\section{References}

Anonymous, (2004). Seaweed harvest. Retrieved from http://www.ausaid.gov.au/publications/focus/sep04 / focus_sept04_14.pdf. Accessed at 10 October 2013.

Anonymous. (2013). Indonesia boosts production of 10 million ton of seaweed. Retrieved from http:// www.investor.co.id/agribusiness/indonesia-genjotproduksi-rumput-laut-10-juta-ton/ 52680. Accessed at July 2013.

AOAC. (1995). Official methods of analysis of the association of official analitycal chemist (pp. 185189).. Inc. Washington DC.

Apriyantono, A. D., Fardiaz, D., Puspitasari, N., Sodarnawati, \& Budiyanto, S. (1989). Food analysis. Pusat Antar Universitas Pangan \& Gizi, IPB, Bogor.

Basmal, J., Syarifudin, \& Ma'ruf, W. F. (2003). Effect of potasium hydroxide on the quality of kappa carrageenan extracted from Eucheuma cottonii. Journal of Marine \& Fisheries Postharvest \& Biotechnology, 11(8), 95-103.

Basmal, J., Sedayu, B. B., \& Utomo, B.S.B. (2009). Quality of semi refined carrageenan ( $S R C$ ) processed using recycled SRC waste water. Journal of Marine \& Fisheries Postharvest \& Biotechnology, 4(1), 1 - 11.

Campo, V. L., Kawano, D. F., da Silva Jr., D. B., \& Carvalho, I. (2009). Review Carrageenans: Biological properties, chemical modifications \& structural analysis. Carbohydrate Polymers, 77, 167-180.

Chapman, V. J. \& Chapman, D. J. (1980). Seaweeds \& their uses ( $p$ 333). 3rd ed. London, New York: Chapman \& Hall.

De Ruiter, G. A. \& Rudolph, B. (1997). Carrageenan biotechnology. Trends in Food Science \& Technology, 8, 389-395.
DKP. (2008). Statistic of Indonesian fisheries (2008). Jakarta: Ministry of Marine affairs \& Fisheries Republic of Indonesia.

Doty, M. S. (1985). Eucheuma alvarezii sp. nov (Gigartinales, Rhodophyta) from Malaysia. In Abbot IA. Norris JN (editors). Taxonomy of Economic Seaweeds ( $p$ 37-45). California Sea Grant College Program.

Ekawati, A. (2010). Indonesia Plans to Limit Seaweed Exports From (2012). Retrieved from http:// www.thejakartaglobe.com/business/indonesiaplans-to-limit-seaweed-exports-from-2012/366886. Accessed at 2 November 2010.

FMC Corp, Marine Colloids. (1977). Carrageenan. Marine Colloid Monograph Number One. Springfield New Jersey, USA: Marine Colloid Division FMC Corporation.

Food and Agriculture Organization (FAO). (2007). Carrageenan. Prepared at the 68th JECFA \& Published in FAO JECFA Monographs 4. p.1-6.

Food Chemical Codex (FCC). (1981). Carrageenan (p.7475). National Academy Press Washington.

Funami, T., Hiroe, M., Noda, S., Asai, I., Ikeda, S., \& Nishinarib, K. (2007). Influence of molecular structure imaged with atomic force microscopy on the rheological behavior of carrageenan aqueous systems in the presence or absence of cations. Food Hydrocolloids, 21, (617-629).

Glicksman, M. (1983). Food Hydrocolloids, II (pp. 74-83). Florida: CRS Press, Inc.

Hakim, A. R., Singgih Wibowo, Arfini, F., \& Rosmawaty, P. (2011). Effect of medium extraction ratio, temperature of precipitation \& potassium chloride concentration on quality of carrageenan. Journal of Marine \& Fisheries Postharvest \& Biotechnology, 6(1), 1-11.

Indriani, H. \& Sumiarsih, E. 1999. Aquaculture, Processing and Marketing of Seaweed ( $7^{\text {th }}$ Edition). Jakarta: PT. Penebar Swadaya.

Istini, S. \& Zatnika, A. 1991. Optimization of semirefine carrageenan process from Eucheuma cottonii. Proceedings of the Scientific Meeting of Seaweed Post Harvest Technology. Book II. Jakarta: Research and Development Center for Fisheries. Indonesian Agency for Agricultural Research and Development. Ministry of Agriculture, Republic of Indonesia.

International Finance Corporation. (2006). Seaweed farming in Indonesia. Monitor: Measuring development results in IFC. Issues 7. p. 4.

Jothisaraswathi , S. B. \& Babu, R. R. (2006). Seasonal studies on alginate and its compasition II : Turbinariaconoides (J. Ag.) Kutz. (Fucales, Phaeophyceae). Journal of Applied Phycocolloid. 18, 161-166.

Marine Colloids. (1978). Raw Material Test Laboratory Standart Practise. Marine Colloids FMC Corp. Springfield, New Jesey. USA.

Marshall, R. D. (2010). Ash analysis. food Analysis (pp. 106-108). West Lafayette: Springer. 
Seaplant. (2008). Laboratory test procedures for raw-dried seaweed and semi-refined carrageenan from Eucheuma and Kappaphycus. Retrieved from http:// www.seaplant.net/bimpeaga/images/downloads/ SPNF HB2H\%201008\%20V3\%20LTP.pdf.

Sudarmadji, S., Haryono, B., \& Suhardi. 1996. Analysis of food and agriculture (p. 79-91). Yogyakarta: Liberty collaborated with PAU Food and Nutrition UGM.

Suryaningrum, T. D. 1988. Study on the quality properties of Seaweed commodity types of Eucheuma cottonii and Eucheuma spinosum (p. 181). Thesis. Postgraduate Programme, Bogor Agricultural University. Bogor.

Suryaningrum, T. D., Murdinah, \& Erlina, M. D. 2003. Effect of Alkali Treatment and volume of extraction solution to the quality of Carragenan from E.cottonii. Journal of
Marine and Fisheries Postharvest and Biotechnology, 9(5), 65-75.

Syamsuar, 2006. Characteristics of carrageenan from Eucheuma cottonii at different harvesting time, $\mathrm{KOH}$ concentration and extraction time. Thesis. Postgraduate Programme, Bogor Agricultural University. Bogor.

Wenno, M. X., Thenu, J. L., \& Lopulalan, C.G.C. 2012. Characteristics of kappa carrageenan from kappaphycus alvarezii at different harvesting times. Short Communication. Journal of Marine and Fisheries Postharvest and Biotechnology, 7(1), 61-68.

Winarno, F. G. 1996. Seaweed processing technology ( $p$. 112). Jakarta: Pustaka Sinar Harapan.

Winarno, F. G. 1997. Chemistry of food and Nutrition (p. 309). Jakarta: PT Gramedia Pustaka Umum. 